\title{
HETEROGENEITY OF HISTOPATHOLOGIC FEATURES IN THE CONGENITALLY CARNITINE-DEFICIENT JUVENILE VISCERAL STEATOSIS (JVS) MOUSE
}

\author{
Isao Narama ${ }^{1}$, Kiyokazu Ozaki ${ }^{1}$, Tetsuro Matsudra ${ }^{1}$, Akira Ono ${ }^{2}$, Masako SeI $^{3}$, Kenji Shima ${ }^{3}$ \\ and MASAMICHI KUWAJIMA ${ }^{3}$ \\ ${ }^{1}$ Research Institute of Drug Safety, Setsunan University, 45-1, Nagaotohgecho, Hirakata, Osaka 573-01, ${ }^{2}$ Second Department of \\ Internal Medicine, Osaka University Medical School, 2-2, Yamadaoka, Suita, Osaka 553, and ${ }^{3}$ Department of Laboratory Medi- \\ cine, School of Medicine, The University of Tokushima 3-18-15, Kuramotocho, Tokushima 770, Japan
}

\begin{abstract}
Carnitine is an essential cofactor for the oxidation of long-chain fatty acids. The morphological features of carnitine deficiency were studied in juvenile visceral steatosis (JVS) mice with congenital carnitine deficiency. Untreated young mice showed marked hepatomegaly associated with fatty liver. In contrast, cardiac hypertrophy and systemic circulatory impairment were the main findings in adult and aged mice with carnitine treatment. The principal lesions common to homozygous mutant mice consisted of the following: 1) accumulation of fat droplets in various kinds of cells (hepatocytes, renal tubular epithelial cells, salivary gland ductal cells, Brünner's gland epithelial cells, brown fat cells, cardiac muscle fibers and striated muscle fibers in the thigh muscles, diaphragm and extrinsic muscle), 2) enlargement of hepatocytes with infrequent hyaline globules in untreated young mice, 3) fine cytoplasmic granules and hypertrophy of cardiac muscle fibers with bizarre nuclei, 4) atrophy of adrenocortical cells, 5) necrosis of lymphocytes in the thymic cortex and spleen, and 6) erosion or ulceration of the gastric mucosa. A wide variety of abnormalities in JVS mice, as reported in humans with carnitine deficiency, strongly suggest the variable and complicated physiological role of carnitine in individual cells or even in the same type of cell at different ages.
\end{abstract}

Juvenile visceral steatosis (JVS) mice were first detected among a breeding colony of $\mathrm{C} 3 \mathrm{H}$ mice by Koizumi et al. in 1988 (17). JVS mice show progressive growth retardation and abdominal swelling due to hepatomegaly from the first or second week of life and about half of the animals die during the peri-weaning period. The characteristic symptoms are fatty change of the visceral organs and the skeletal muscles, progressive cardiac hypertrophy, and hyperammonemia resulting from disordered beta-oxidation. These symptoms are inherited in an autosomal recessive manner (9).

Correspondence to: Masamichi Kuwajima at the above address. Tel: (81) (886) 33 7184; Fax: (81) (886) 31 9495
It was reported in 1991 that JVS mice suffer from systemic carnitine deficiency (18). The deficiency was thought to result from a disorder of the renal carnitine transport system (11). Recent studies have confirmed the presence of a carnitine transport defect in the fibroblasts of these mice and they are presently considered as a suitable animal model for primary carnitine deficiency (19). JVS mice have disordered expression of urea cycle enzymes $(12,15,28)$, proto-oncogenes (29), carnitine palmitoyltransferase I and II $(14,30)$ and glycolytic and gluconeogenic enzymes (13).

As there have been few reports on histological changes associated with carnitine deficiency in humans and animals $(3,6,16)$, we have reported on mitochondrial abnormalities in muscle tissue in 
Table 1 L-Carnitine Treatment and Main Clinical Signs in JVS Mice

\begin{tabular}{|c|c|c|c|c|c|c|c|c|c|}
\hline \multirow[b]{2}{*}{$\begin{array}{l}\text { Case } \\
\text { No. }\end{array}$} & \multirow[b]{2}{*}{$\begin{array}{c}\text { Age } \\
\text { (weeks) }\end{array}$} & \multirow[b]{2}{*}{ Sex } & \multicolumn{2}{|c|}{ Treatment } & \multicolumn{5}{|c|}{ Main clinical signs } \\
\hline & & & $\begin{array}{c}\text { Duration } \\
\text { (days) }\end{array}$ & $\begin{array}{l}\text { Dosage } \\
\text { (/head) }\end{array}$ & $\begin{array}{l}\text { Growth } \\
\text { retardation }\end{array}$ & $\begin{array}{l}\text { Abdominal } \\
\text { swelling }\end{array}$ & $\begin{array}{c}\text { Continuous } \\
\text { shivering }\end{array}$ & Ascites & $\begin{array}{c}\text { Subcutaneous } \\
\text { edema }\end{array}$ \\
\hline 1 & $2 W$ & $\mathrm{~F}$ & 0 & 0 & + & + & - & - & - \\
\hline 2 & $3 \mathrm{~W}$ & $\mathrm{~F}$ & 0 & 0 & + & + & - & - & - \\
\hline 3 & $4 \mathrm{~W}$ & $\mathrm{~F}$ & 0 & 0 & + & + & + & - & - \\
\hline 4 & $4 \mathrm{~W}$ & $\mathrm{M}$ & 0 & 0 & + & + & + & - & - \\
\hline 5 & $4 \mathrm{~W}$ & $\mathrm{M}$ & 0 & 0 & + & + & + & - & - \\
\hline 6 & $4 \mathrm{~W}$ & $\mathrm{~F}$ & 0 & 0 & - & + & + & - & - \\
\hline 7 & $4 \mathrm{~W}$ & $\mathrm{~F}$ & 0 & 0 & - & + & + & - & - \\
\hline 8 & $2 \mathrm{~W}$ & $\mathrm{M}$ & $10-14$ & $1 \mathrm{mg}$ & + & + & - & - & - \\
\hline 9 & $2 \mathrm{~W}$ & $\mathrm{M}$ & $10-14$ & $1 \mathrm{mg}$ & + & + & - & - & - \\
\hline 10 & $3 \mathrm{~W}$ & $\mathrm{M}$ & $10-21$ & $1 \mathrm{mg}$ & - & - & - & - & - \\
\hline 11 & $4 \mathrm{~W}$ & $\mathrm{~F}$ & $10-21$ & $1 \mathrm{mg}$ & + & + & + & - & - \\
\hline 12 & $4 W$ & $\mathrm{M}$ & $10-21$ & $1 \mathrm{mg}$ & + & + & + & - & - \\
\hline 13 & $4 W$ & $\mathrm{M}$ & $10-21$ & $1 \mathrm{mg}$ & + & + & + & - & - \\
\hline 14 & $8 \mathrm{~W}$ & $\mathrm{~F}$ & $10-56$ & $1 \mathrm{mg}$ & - & - & - & - & - \\
\hline 15 & $8 \mathrm{~W}$ & $\mathrm{M}$ & $10-56$ & $1 \mathrm{mg}$ & - & - & - & - & - \\
\hline 16 & $8 W$ & M & $10-21$ & $1 \mathrm{mg}$ & + & - & + & - & - \\
\hline 17 & $8 W$ & $\mathrm{~F}$ & $10-21$ & $1 \mathrm{mg}$ & + & - & + & - & - \\
\hline 18 & $8 \mathrm{~W}$ & $\mathrm{~F}$ & $10-50$ & $1 \mathrm{mg}$ & + & - & + & - & - \\
\hline 19 & $8 \mathrm{~W}$ & $\mathrm{~F}$ & $10-50$ & $1 \mathrm{mg}$ & + & - & - & - & - \\
\hline \multirow[t]{2}{*}{20} & $24 \mathrm{~W}$ & $\mathrm{M}$ & $10-50$ & $1 \mathrm{mg}$ & - & - & - & - & - \\
\hline & & & $30-160$ & $2 \mathrm{mg}$ & & & & & \\
\hline 21 & $32 \mathrm{~W}$ & $\mathrm{~F}$ & $10-30$ & $1 \mathrm{mg}$ & - & - & + & - & - \\
\hline 22 & $32 \mathrm{~W}$ & $\mathrm{~F}$ & $10-30$ & $1 \mathrm{mg}$ & - & + & + & + & + \\
\hline \multirow[t]{2}{*}{23} & $40 \mathrm{~W}$ & $\mathrm{M}$ & $10-30$ & $1 \mathrm{mg}$ & - & + & + & + & + \\
\hline & & & $31-270$ & $2 \mathrm{mg}$ & & & & & \\
\hline \multirow[t]{2}{*}{24} & $52 \mathrm{~W}$ & $\mathrm{M}$ & $10-30$ & $1 \mathrm{mg}$ & - & + & + & + & + \\
\hline & & & $31-300$ & $2 \mathrm{mg}$ & & & & & \\
\hline \multirow[t]{2}{*}{25} & $56 \mathrm{~W}$ & $\mathrm{M}$ & $10-30$ & $1 \mathrm{mg}$ & - & + & + & + & + \\
\hline & & & $31-300$ & $2 \mathrm{mg}$ & & & & & \\
\hline
\end{tabular}

JVS mice $(10,22)$. In this paper we examined the histological and electron microscopic features of organs other than the heart and skeletal muscle in JVS mice to help clarifying the tissue and cellular changes caused by carnitine deficiency.

\section{MATERIALS AND METHODS \\ Animals}

Homozygous mutant (jvs/jvs) mice were distinguished from clinically normal heterozygous (jvs/ + ) or homozygous control $(+/+$ ) littermates by yellowish discoloration of the liver that was detectable through the abdominal wall within 5 days of birth. Intraperitoneal injection of carnitine (10) allowed homozygous mice to survive to adulthood and to breed. Thus, homozygous mutant (jvs/jvs) and heterozygous (jvs/ + ) mice were obtained by back cross mating and identified from an early age. Homozygous control $(+/+)$ mice were obtained from normal stock of the $\mathrm{C} 3 \mathrm{H}$ strain. Table 1 shows the data on the JVS (jvs/jvs) mice used in the present study. Among the animals sacrificed at 2 and 4 weeks of age, 7 (Nos. 1-7) were untreated. Marked growth retardation and abdominal distention due to liver enlargement were observed in all of them, while continuous shivering was noted before autopsy in 5 animals sacrificed at 
4 weeks of age. L-Carnitine was administered intraperitoneally to all other animals (Nos. 8-25). Carnitine was administered at a dose of $1 \mathrm{mg} /$ day from day 10 of life and the dose was increased to 2 $\mathrm{mg} /$ day from day 30 or 31 in some animals (Nos. $20,23,24$ and 25). Growth retardation, abdominal distention due to liver enlargement, sedation and continuous shivering suggesting increased sensitivity to cold were noted in some of carnitine-treated animals as well as in the untreated group. Weakness, abdominal distention and subcutaneous edema developed within 1 month of drug withdrawal in 4 of the 5 mice that survived for longer than 8 months. The period from the cessation of treatment to the onset of symptoms varied between animals. An animal (No. 20) died suddenly 7 days after drug withdrawal with no obvious symptoms before death. All mice were sacrificed by exsanguination from the abdominal aorta under deep ether anesthesia and necropsied immediately after death. The mice examined included 25 homozygous mutant (jvs/jvs) mice aged from 2 weeks to 13 months, 17 heterozygous (jvs/+) mice and 18 age-matched control $(+/+)$ mice.

\section{Light Microscopy}

Tissues and organs subjected to light microscopy included the brain, eyeballs, pituitary gland, tongue, esophagus, stomach, duodenum, jejunum, ileum, cecum, colon, rectum, liver, spleen, pancreas, salivary glands, heart, lungs, trachea, aorta, thyroid glands, kidneys, urinary bladder, seminal vesicle, prostatic glands, testes, adrenal glands, uterus, ovaries, vagina, skin with mammary gland, skeletal muscle, sciatic nerve and lymph nodes. These tissues and organs were fixed in $10 \%$ buffered formalin immediately after necropsy, dehydrated, and embedded in paraffin wax by an automated tissue processor. Then sections $5 \mu \mathrm{m}$ thick were cut and stained with hematoxylin and eosin.

\section{Electron Microscopy}

Tissue fragments from the kidney, liver and adrenal gland were fixed in $2 \%$ glutaraldehyde solution (pH 7.4) overnight, postfixed in $1 \%$ osmium tetroxide solution ( $\mathrm{pH} 7.4$ ) for $2 \mathrm{~h}$., dehydrated in a graded series of ethanol and embedded in epoxy resin. Semi-thin sections were cut and stained with toluidine blue. Ultra-thin sections were cut and stained with uranyl acetate and lead citrate and examined under an electron microscope (JEM 1200EX, JEOL).

\section{RESULTS}

\section{Necropsy Findings}

Moderate to severe enlargement of the liver with tan coloration was the most common macroscopic finding among the untreated homozygous mutant mice. The kidneys remained within the normal size range, but were more yellowish in color than those of heterozygous and control mice. About half of the untreated homozygous mutant mice under 4 weeks of age showed excess fat deposition in the subcutaneous tissue. Cardiac hypertrophy with an increased heart weight was constantly observed in all homozygous mutant mice and the degree of hypertrophy increased with age. However, the shape and color of the affected hearts remained normal. Tan coloration of the liver was also noted in the elderly animals, but its size remained normal. In two moribund animals (Case Nos. 23 and 25), gelatinous change of the subcutaneous adipose tissue and retention of transparent thoracic and/or abdominal fluid were also observed in addition to these findings. Brown fat was not obvious in the homozygous mutant mice, but no gross changes were detected in the other organs.

No significant changes were detected at necropsy in the heterozygous mice and normal control mice.

\section{Microscopic Findings}

The common lesions found in homozygous mutant mice consisted of the following: 1) accumulation of fat droplets in various kinds of cells, 2) enlargement of hepatocytes with infrequent hyaline globules, 3) cytoplasmic fine granules, hypertrophy and bizarre nuclei in cardiac myocytes, 4) atrophy of adrenocortical cells, 5) necrosis of lymphocytes in the thymic cortex and splenic follicles, and 6) erosion or ulceration of the gastric mucosa. These changes were not observed in heterozygous mice or normal control mice.

Fat droplets were seen in the cytoplasm of hepatocytes, renal tubular epithelial cells, salivary gland duct cells, Brünner's gland epithelial cells, brown fat cells, cardiac myocytes, and striated muscle fibers in the thigh muscles, diaphragm and extrinsic muscle. These droplets were usually rather small, but some cells (especially hepatocytes) occasionally contained large droplets filling the whole cytoplasm. Brown fat cells showed an increase in size 


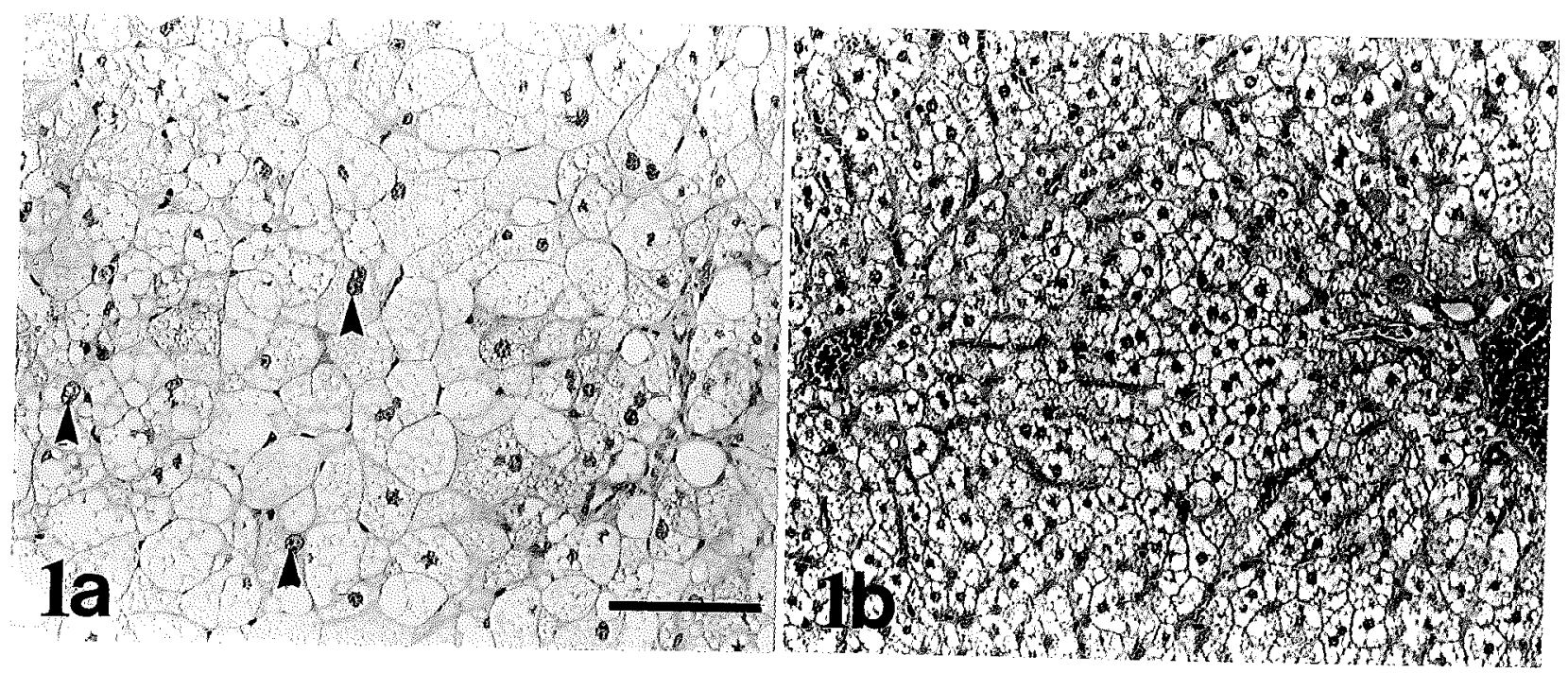

Fig. 1 Light micrograph of the liver of JVS mice. Accumulation of fat droplets in the hepatocytes. The size of hepatocytes of 4-week-old mouse (a) was much larger than that of 13-month-old mouse (b). Nuclear enlargement was also prominent in some hepatocytes (arrowheads) in the case without carnitine treatment. Hematoxylin-eosin staining (HE). Bar, $100 \mu \mathrm{m}$

and decrease in the number of droplets that was inversely proportional to the increasing size. Following the accumulation of large droplets, the centrally located nuclei of brown fat cells were pushed to the periphery. Severely affected brown fat was indistinguishable from white fat under the microscope, except for the round nuclei and scanty eosinophilic cytoplasm remaining in the perinuclear area.

The cytoplasm of affected hepatocytes was markedly enlarged, especially in young untreated mice under 4 weeks of age, being filled with many fat droplets (Fig. 1a) and occasional eosinophilic globules. However, neither necrosis nor proliferative changes were detected in the hepatocytes and other cells. In the carnitine-treated mice, the number of fat droplets was reduced to a variable extent and the hepatocytes remained within the normal size range (Fig. 1b), even in moribund mice long after the cessation of treatment.

Atrophy of adrenocortical cells was most conspicuous in the deep cortical area. In contrast to the lipid droplet-rich adrenocortical cells of heterozygous and control mice (Fig. 2a), the cortical cells of the zona fasciculata contained only a few lipid droplets in scanty cytoplasm with a homogeneous appearance like that of hepatocytes. Atrophy was more prominent in the deeper area and the cortical cells showed dissociation (Fig. 2b). Pyknotic cells or apoptotic bodies were also seen in the $\mathrm{X}$ zone of female mice.

Cortical lymphocytes of the thymus showed widespread necrosis and acute involution (Fig. 3). Karyorrhexis or apoptosis of lymphocytes was also observed in the white pulp of the spleen (Fig. 4) and the paracortical regions of follicles in lymph nodes and Peyer's patches, with a decrease in the number of lymphocytes. Acute erosion of the glandular gastric mucosa or an increase of mitotic figures in the neck area of the fundic glands (Fig. 5) were detected in some animals with severe thymic involution.

\section{Electron Microscopic Findings}

Hepatocytes in untreated JVS mice ( 2 and 4 weeks of age) were full of small and large fat droplets. The larger fat droplets were the same size as the nucleus and the hepatocytes themselves were remarkably enlarged. Although the number of mitochondria per unit area was decreased due to the increase of fat droplets, the number in each cell was probably unchanged (Fig. 6a). Fat droplets were increased in number in the hepatocytes of JVS mice administered carnitine for 12 months followed by discontinuation of administration, but were all smaller than those found in the livers of 2 week-old mice (Fig. 6b). In the kidneys, small and large fat droplets were accumulated in the cytoplasm of the proximal convoluted tubular cells 


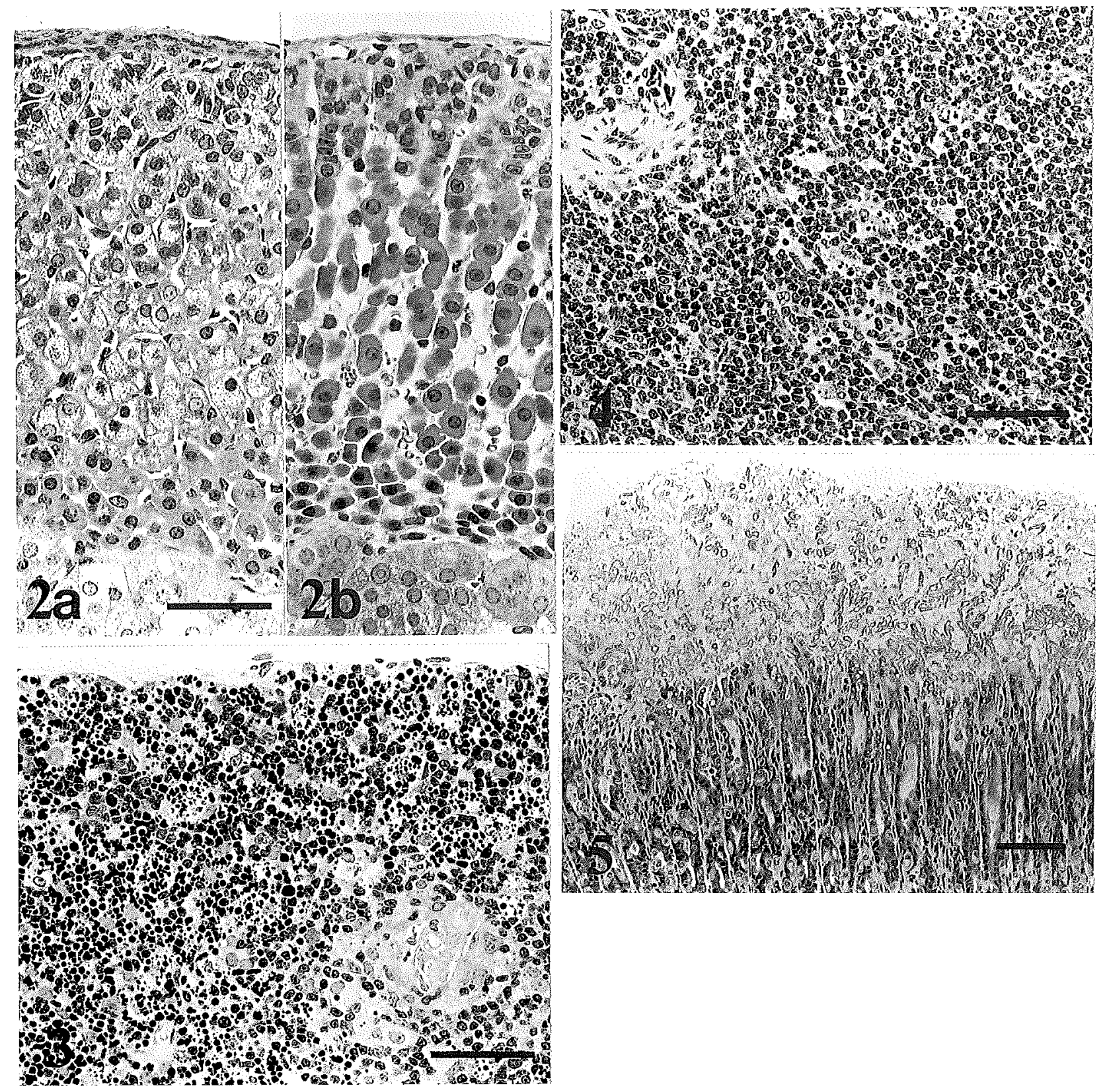

Fig. 2 Light micrograph of the adrenal gland of 8-week-old JVS and control mice. Cortical cells in JVS mouse (b) contained less amount of fat droplets in their cytoplasm and took normal hepatocyte-like appearance in fascicular zone. Smaller population of cortical cells and atrophic cells with pyknotic nuclei in reticular zone comparing those of age-matched control (a). HE. Bar, $50 \mu \mathrm{m}$

Fig. 3 Light micrograph of the thymus of a JVS mouse. Acute involution with severe karyorrhexis (apoptosis) in cortical lymphocytes. HE. Bar, $50 \mu \mathrm{m}$

Fig. 4 Light micrograph of the spleen of a JVS mouse. Apoptotic lymphocytes in periarterial lymphoid sheath of white pulp. HE. Bar, $50 \mu \mathrm{m}$

Fig. 5 Light micrograph of the stomach of a JVS mouse. Severe erosion of gastric mucosa. HE. Bar, $100 \mu \mathrm{m}$ 


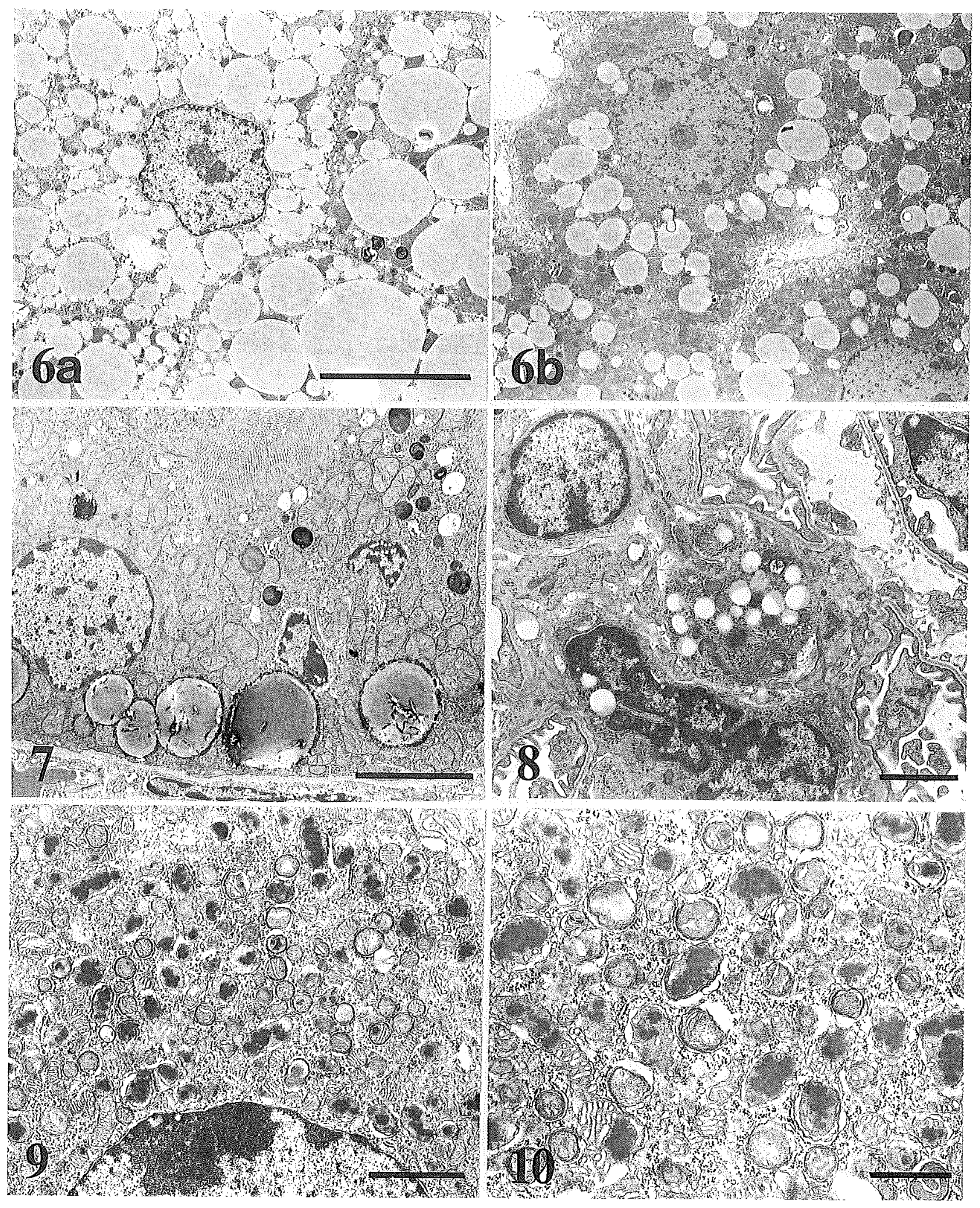

Figs. 6-10 
(Fig. 7). In addition, small fat droplets were accumulated in the cytoplasm of the mesangial cells of the glomerulus (Fig. 8). Accumulation of fat droplets was mainly seen in the epithelial cells of the proximal tubules and not in the cells of the distal convoluted tubules or collecting ducts. The number and morphology of the mitochondria in the fat-laden cells was also not significantly different from that in the control mice and the microvilli of the brush border also remained normal.

In JVS mice, the numerous fat droplets usually recognized in adrenocortical cells were almost absent. Although there was no abnormality in the number of mitochondria and in the development of the cristae, electron-dense substances were seen in many of the mitochondria. Some of the dense deposits were an amorphous substance, which was found in all the mitochondria and had a flocculent appearance (Figs. 9 and 10). The mitochondria with a flocculent appearance were enlarged and deformed and some showed breakdown of the membrane structure.

\section{DISCUSSION}

Carnitine is an essential cofactor for the oxidation of long-chain fatty acids and is thought to be involved in the transport of fatty acids across

Fig. 6 Electron micrograph of the hepatocytes of JVS mice. The size and number of accumulated fat droplets were much larger in non-treated 4-week-old mouse (a) than treated 13-month-old mouse (b). Bar, $10 \mu \mathrm{m}$

Fig. 7 Electron micrograph of the kidney of an 8week-old JVS mouse. Accumulation of large fat droplets in the basal side of renal epithelial cells of proximal convoluted tubules. The number and morphology of the mitochondria was not significantly different from that in control animal and microvilli of the brush border remained intact. Bar, $5 \mu \mathrm{m}$

Fig. 8 Electron micrograph of the kidney of an 8 week-old JVS mouse. Accumulation of small fat droplets in the mesangial cells. Bar, $2 \mu \mathrm{m}$

Fig. 9 Electron micrograph of the adrenal gland of a 4 week-old JVS mouse. Flocculent appearance of mitochondria and loss of fat droplets in the cortical cells from fascicular zone. Bar, $2 \mu \mathrm{m}$

Fig. 10 Electron micrograph of the adrenal gland of a 4-week-old JVS mouse. Amorphous dense deposits in the mitochondrial matrix showing so-called 'flocculent appearance'. Loss of cristae and destruction of inner and outer membrane in mitochondria with severe deposition. Bar, $1 \mu \mathrm{m}$ the inner mitochondrial membrane. However, the effect of carnitine deficiency on the function and morphology of various cells or organs is not well understood, because the physiological role of carnitine in fat metabolism is very complicated and the mechanism of carnitine uptake varies between different cells and organs (7, 25). A wide variety of abnormalities have been reported in patients as syndromes associated with primary or secondary carnitine deficiency including lipid storage myopathy $(1,2,4,5,8,16,24,31)$, Reye's syndrome $(20,23,27)$, nonketotic hypoglycemia (26) and cardiomyopathy $(21,32)$. Along with the miscellaneous causes of secondary carnitine deficiency, these findings strongly suggest a variable and complicated physiological role of carnitine in individual cells or even in the same type of cell at different ages.

One of the most conspicuous histological change in our JVS mice was the accumulation of fat droplets in various kinds of cells. Striated muscle fibers, hepatocytes, renal tubular epithelial cells, salivary gland ductal epithelial cells and brown fat cells were commonly affected. In moribund animals, evidence of systemic circulatory failure, such as subcutaneous edema and retention of intrathoracic and abdominal fluid, was the main necropsy findings. Therefore, cardiac failure was thought to be a major factor in the death of adult or aged mice with carnitine deficiency. Although cerebral edema was not evident in infant or young mice despite the pathologic changes similar to Reye's syndrome, hyperammonemia was thought to be the main cause of death in these mice. These results also suggest that there were differences in the metabolic role of carnitine with aging in our mice.

Although brown fat is one of the main organs for heat production especially in young animals, little is known about the influence of carnitine on lipid metabolism in this tissue. In rodents, brown fat is retained until a fairly old age, suggesting that it remains a major energy source throughout life. Accumulation of large fat droplets in the brown fat tissue might cause the higher sensitivity to cold of JVS mice. However, it remains unclear if the accumulation of fat droplets was the primary cause of the decreased function of brown fat cells or simply resulted from the inability to properly utilize fatty acids for energy.

Acute thymic involution and erosion of the glandular stomach are common pathological changes following severe stress. The increased number of mitotic figures in the fundic gland necks of some 
animals would also reflect prior gastric mucosal erosions. These changes were more severe in the animals that showed continuous shivering at the moribund stage. Exposure of rodents to cold water is well-known to accelerate the experimental gastric erosions or ulceration. A reduced body temperature due to dysfunction of heat production in the present mice is thought to be another stressor in addition to fasting in the moribund state. The decrease of fat droplets in the adrenocorticl cells also suggested stress overload in these mice. However, the pathogenesis of atrophy in the deep cortex remains unclear.

The mechanism of fatty change in the renal tubular epithelial cells or salivary gland ductal epithelial cells also remains unclear. Further investigation of lipid metabolism in these cells, including the role of carnitine, is needed for clarification of the pathogenesis and significance of such fat accumulation.

A flocculent appearance (especially observed by electron microscopy) in the adrenals has rarely been reported. We also considered that a change from cellular atrophy to loss was evidence of cell death at the electron microscopic level. However, it is not certain that this change is directly related to carnitine-deficiency in JVS mice.

This study was supported in part by grants from the Ministry of Education, Science and Culture of Japan and from the Ono Medical Research Foundation.

\section{Received 26 March 1997; and accepted 17 April 1997}

\section{REFERENCES}

1. Bank W. J., DiMauro S., Bonilla E., Capuzzi D. M. and Rowland L. P. (1975) A disorder of muscle lipid metabolism and myoglobinuria. Absence of carnitine palmitoyltransferase. N. Engl. J. Med. 292, 443-449

2. Boudin G., Mikol J., Giullard A. and Engel A. G. (1976) Fatal systemic carnitine deficiency with lipid storage in skeletal muscle, heart, liver and kidney. J. Nellol. Sci. 30, 313-325

3. Chapoy P. R., Angelini C., Brown W. L., Stiff J. E., Shug A. L. and Cederbaum S. D. (1980) Systemic carnitine deficiency: a treatable inherited lipid-storage disease presenting as Reye's syndrome. N. Engl. J. Med. 303, 1389-1394

4. DiDonato S., Cornelio F., Balestrini M. R. and Peluchetti D. (1978) Mitochondria-lipid-glycogen myopathy, hyperlactacidemia, and carnitine deficiency. Neurology 28, $1110-1116$

5. DiMauro S. and Meirs-DiMauro P. (1973) Muscle carnitine palmityl-transferase deficiency and myoglobinuria. Science 182, 929-931

6. Engel A. G., Banker B. Q. and Eiben R. M. (1977) Car- nitine deficiency: clinical, morphological, and biochemical observations in a fatal case. J. Neurol. Neurosurg. Psychiatry 27, 174-181

7. Engel A. G. and Rebouche C. J. (1984) Carnitine metabolism and inborn errors. J. Inherited Mitab. Dis. 7, Suppl. 1, $38-43$

8. Engle A. G., Siekert R. G. and Minn R. (1972) Lipid storage myopathy responsive to prednisone. Arch. Neurol. 40, 313-322

9. HayaKawa J., Kolzumi T. and Nikaido H. (1990) Inheritance of juvenile steatosis of viscera (JVS) found in $\mathrm{C} 3 \mathrm{H}-\mathrm{H}-$ $2^{\circ}$. Mouse Genome 86, 261

10. Horiuchi M., Kobayashi K., Tomomura M., Kuwajima M., Imamura Y., Kolzumi T., Nikaido H., HayaKaWa J. and SAHeKI T. (1992) Carnitine administration to juvenile visceral steatosis mice corrects the suppressed expression of urea cycle enzymes by normalizing their transcription. $J$. Biol. Chem. 267, 5032-5053

11. Horiuchi M., Kobayashi K., Yamaguchi S., Shimizu T., Koizumi T., Nikaido H., HayaKawa J., Kuwajima M. and SAHEKI T. (1994) Primary defect of juvenile visceral steatosis (JVS) mouse with systemic carnitine deficiency is probably in renal transport system. Biochim. Biophys. Acta 1226, $25-30$

12. Horiuchi M., Yoshida H., Kobayashi K., Kuriwaki K., Yoshimine K., Tomomura M., Koizumi T., Nikaido H., Hayakawa J., Kuwajima M. and SaheKI T. (1993) Cardiac hypertrophy in juvenile visceral steatosis (JVS) mice with systemic carnitine deficiency. FEBS Lett. 326, 267-271

13. Hotta K., Kuwajima M., ONo A., Nakajima H., Horikawa Y., Miyagawa J., Namba M., Hanafusa T., Horiuchi M., Nikaido H., Hayakawa J., Saheki T., Kono N., Noguchi T. and Matsuzawa Y. (1996) Disordered expression of glycolytic and gluconegenic liver enzymes of juvenile visceral steatosis mice with systemic carnitine deficiency. Biochim. Biophys. Acta 1289, 131-135

14. Hotta K., Kuwajima M., Ono A., Uenaka R., Nakajima H., Miyagawa J., Namba M., Hanafusa T, Horiuchi M., Nikaido H., Hayakawa J., Kono N., Saheki T. and Matsuzawa Y. (1996) Altered expression of carnitine palmitoyltransferase II in liver, muscle, and heart of mouse strain with juvenile visceral steatosis. Diabetes Res. Clin. Pract. 32, 117-123

15. Imamura Y., Saheki T., Arakawa H., Noda T., Kolzumi T., Nikaido H. and Hayakawa J. (1990) Urea cycle disorder in $\mathrm{C} 3 \mathrm{H}-\mathrm{H}-2^{\circ}$ mice with juvenile steatosis of viscera. FEBS Lett. 260, 119-121

16. Karpati G., Carpenter S., Engel A. G., Watters G., Allen J., Rothman S., Klassen G. and Mamer O. A. (1975) The syndrome of systemic carnitine deficiency: clinical, morphologic, biochemical, and pathophysiologic features. Newrology 25, 16-24

17. Koizumi T., Nikaido H., Hayakawa J., Nonomura A. and YoNEDA T. (1988) Infantile disease with microvesicular fatty infiltration of viscera spontaneously occurring in the $\mathrm{C} 3 \mathrm{H}-\mathrm{H}-2^{\circ}$ strain of mice with similarities to Reye's syndrome. Lab. Anim. 22, 83-87

18. Kuwajima M., Kono N., Horiuchi M., Imamura Y., Ono A., Inui S., Kawata S., Koizumi T., Hayakawa J., Saheki T. and TARUi S. (1991) Animal model of systemic carnitine deficiency: Analysis in $\mathrm{C} 3 \mathrm{H}-\mathrm{H}-2^{\circ}$ strain of mouse associated with juvenile visceral steatosis. Biochem. Biophys. Res. Commlin. 174, 1090-1094 
19. Kuwajima M., Lu K., Harashima A., Ono A., Sato I., Mizuno A., Murakami T., Nakajima H., Miyagawa J., Namba M., Hanafusa T., Hayakawa J., Matsuzawa Y. and SHIMA K. (1996) Carnitine transport defect in fibroblast of juvenile visceral steatosis (JVS) mouse. Biochem. Biophys. Res. Commun. 223, 283-287

20. Matsubasa T., Ohtani Y., Minke T., Kitano A., Endo F. and Matsuda I. (1986) Carnitine prevents Reye-like syndrome in atypical carnitine deficiency. Pediat. Neurol. 2, $80-84$

21. Matsuishi T., Hirata K., Terasawa K., Kato H., YoshiNo M., OHtaki E. and Hirose F. (1985) Successful carnitine treatment in two siblings having lipid storage myopathy with hypertrophic cardiomyopathy. Neuropediatrics 16, 6-12

22. Miyagawa J., Kuwajima M., Hanafusa T,, Ozaki K., Fujimura H., Ono A., Uenaka R., Narama I., Oue T.,

- Yamamoto K., Kaidoh M., Nikaido H., Hayakawa J., Horiuchi M., SaheKi T. and Matsuzawa Y. (1995) Mitochondrial abnormalities of muscle tissue in mice with juvenile visceral steatosis associated with systemic carnitine deficiency. Virchows Arch, 426, 271-279

23. Ohtani Y., Endo F. and Matsuda I. (1982) Carnitine deficiency and hyperammonemia associated with valproic acid therapy. J. Pediatr: 101, 782-785

24. Scarlato G., Albizatti M. G., Bassi S., Cerri C. and Frattola L. (1977) A case of lipid storage myopathy with carnitine deficiency: Biochemical and electromyographic correlations. Eur. Neurol. 16, 222-229

25. Schmidt-Sommerfeld E., Penn D. and Wolf H. (1983) Carnitine deficiency in premature infants receiving total parenteral nutrition: Effect of $\mathrm{L}$-carnitine supplementation. $J$.
Pediatr: 102, 931-935

26. Stanley C. A., Hale D. E., Coates P. M., Hall C. L., Corkey B. E., Yang W., Kelley R. I., Gonzales E. L., WILLIAMSON J. R. and BAKER L. (1983) Medium-chain acyl-CoA dehydrogenase deficiency in children with nonketotic hypoglycemia and low carnitine levels. Pediatr. Res. $17,877-884$

27. Stumphy D. A., Parker W. D. and Angelini C. (1985) Carnitine deficiency, organic acidemias and Reye's syndrome, Neurology 35, 1041-1045

28. Tomomura M., Imamura Y., Horiuchi M., Kolzumi T., Nikaido H., Hayakawa J. and Saheki T. (1992) Abnormal expression of urea cycle enzyme genes in juvenile visceral steatosis (JVS) mice. Biochim. Biophys. Acta 1138, 167171

29. Tomomura M., Nakagawa K. and Saheki T. (1992) Protooncogene c-jun and c-fos messenger RNAs increase in the liver of carnitine-deficient juvenile visceral steatosis (JVS) mice. FEBS Lett. 311, 63-66

30. Uenaka R., Kuwajima M., Ono A., Matsuzawa Y., Hayakawa J., Inohara N., Kagawa Y. and Ohta S. (1996) Increased expression of carnitine palmitoyltransferase I gene is repressed by administration of L-carnitine in the hearts of carnitine deficient juvenile visceral steatosis mice. J. Biochem. 119, 533-540

31. VanDyke D. H., Griggs R. C., Markesbery W. and DiMauro S. (1975) Hereditary carnitine deficiency of muscle. Neurology 25, 154-159

32. Waber L. J., Valle D., Neill C., DiMauro S, and Shug A. (1982) Carnitine deficiency presenting as familial cardiomyopathy: a treatable defect in carnitine transport. $J$. Pediatr: 101, 700-705 